\title{
German university faces ban on animal tests in class
}

Munich. The department of zoology at the University of Marburg in Germany has been told by the local Hessen government to stop using experiments on anaesthetized rats as part of an undergraduate teaching course in animal physiology.

The Hessen government, which is led by the Green Party, says that it eventually wants to ban the use of animals from all undergraduate courses. But the university is appealing against the injunction, claiming that it is neither in the interests of students nor in the long-term interests of society.

The row began five years ago, and has centred on a single experiment to study the intestinal absorption of glucose in an anaesthetized rat, the only animal experiment now left during the whole of the course.

The main aim of the experiment, according to Gerald Heldmaier, the head of the zoology department, is to teach students about the control of anaesthesia, and introduce them to simple surgical techniques. In each case, students must pass a test on the relevant theory in advance.

Germany's animal protection law states that animal experiments may be carried out for teaching purposes only where no viable alternative exists. Students at the university argue that the experiment could be replaced by a film which they themselves made four years ago. But Heldmaier, who has wide support among his colleagues, maintains that practical experience is an essential component of his course.

Last February, the research minister of Hessen sent a letter to the university stating that its long-term aim is to ban the use of both whole animals and parts of animals in teaching. In reply, 63 professors at the university signed an appeal saying that such a move would lower the standards of education and endanger the quality of future researchers.

According to Heldmaier, discussions that had been promised between the university and the Land government failed to materialize. And this summer, the students stepped up their protests by taking out a private legal action accusing Heldmaier of coercion in making the experiment a course requirement, and of violating the country's animal protection act.

Over the past few years, about 20 students out of an average of 100 taking the animal physiology course have refused to carry out the experiment. On graduation, they have been awarded a 'qualified' certificate, indicating that they did not complete this part of the course.

Irvana Weber, a spokesperson for the students, says that their main criticism is that the experiment is mandatory for all students. Heldmaier replies that only those majoring in zoology are required to conduct it; others majoring in disciplines that would not lead to careers working with animals can choose whether or not to do so.

Support for Heldmaier has come from the German Physiological Society. Earlier this year it adopted a resolution, signed by nearly all of Germany's physiology professors, stating that the nature of their subject requires students to complete practical experiments on animals or parts of animals. Last week the society wrote to Heldmaier saying they believed this also to be true of zoology.

Alison Abbott

\section{Cloning of human embryos draws fire from critics}

Washington. Critics of research announced earlier this month which has succeeded in cloning human embryo cells for the first time have pledged to block any repetition of it in court and in Congress.

The successful cloning of the embryo cells - which surfaced discreetly at a lowkey meeting of fertility researchers on 13 October - is certain to reopen a fierce debate about the ethical boundaries of human embryo research.

Science activist Jeremy Rifkin described the research, which applied techniques commonly used to clone animal embryos, as "very troubling". He accused the researchers involved - Robert Stillman and Jerry Hall of the in vitro fertilization department at George Washington University Medical Center in Washington - of doing work "of no redeeming value" just because "they wanted to see if it would work".

Stillman says that research, which was approved by the Medical Center's ethics committee, involved only genetically abnormal embryos which had been penetrated by more than one sperm, and could not have become viable.

He says that the results "indicate that the process has the potential for reducing risks and costs as well as enhancing success rates for infertile couples who desire children." Stillman adds that the experiment has no clinical value for now, but should be regarded as a "small step in an on-going scientific process".

In the experiment, 17 embryos consisting of a few cells each were divided into 48 single cells, covered in a coating developed by Hall and placed in a culture. The single cells divided an average of three times before dying; some of them survived to divide five times, into 32-cell embryos.

The research was first reported at a joint meeting of the American Fertility Society and the Canadian Fertility and Andrology Society. It was part of a series of studies aimed at helping infertile couples. But Hall and Stillman say that the research which produced the cloned embryos has now ceased.

Although the work at GWU is not funded by US fedcral agencies, Rifkin's lobby group, the Foundation on Economic Trends, has filed a petition asking the National Institutes of Health (NIH) to halt all funding of "institutions working on human cloning."

Such a sanction would effectively bar even privately-funded work from taking place in any US university. If NIH refuses to act, Rifkin has promised to follow through with legal action. He has also called on members of Congress to make all human cloning illegal in the United States.

Colin Macilwain 